\title{
404 アルミニウム合金の延性に及ぼす水素の影響
}

\section{Effect of hydrogen on the ductility of aluminum alloys}

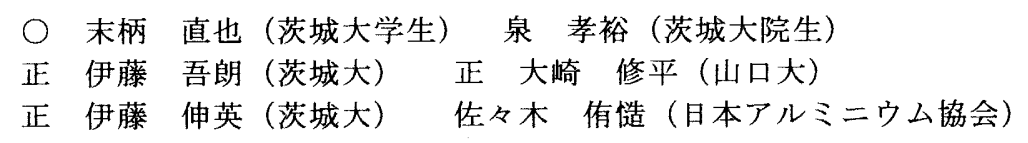

Naoya SUEGARA, Student, Ibaraki University

Takahiro IZUMI, Graduate Student, Ibaraki University

Goroh ITOH, Ibaraki University

Shuhei OSAKI, Yamaguchi University

Nobuhide ITOH, Ibaraki University

Yuzo SASAKI, Japan Aluminum Association

In late years with worsening of the global environmental state, regulation of $\mathrm{CO}_{2}$ emission has become more severe to suppress global warming. Therefore, fuel cell vehicles (FCV's) come into the limelight particularly in the automobile industry. It is suggested that the FCV's should be equipped with a tank with highly compressed hydrogen gas consisting of aluminum alloy liner materials. On the other hand, it is known that some aluminum alloys cause hydrogen embrittlement, when they are stretched in the humid atmosphere. Thus, in this study, slow-strain-rate technique tensile tests were carried out in the atmosphere where humidity was precisely controlled, and the effect of hydrogen on the ductility of various aluminum alloys was examined. As a result, in a 6061-T6 sheet, elongation did decrease at all when testing atmosphere was changed from dry nitrogen gas to humid air, irrespective of strain rate, that is, hydrogen embrittlement was not detected. For a 7075-T6 sheet, elongation falls significantly with the above change in the atmosphere as the strain rate decreases, which means that sensitivity to hydrogen embrittlement is high. In the 7075-T6, hydrogen generated at the alloy surface during the test was deduced to invade the interior of the material, to reduce the bonding strength of grain boundaries, and finally to cause hydrogen embrittlement based on intergranular fracture.

Key Words: 6061 aluminum alloy, 7075 aluminum alloy, hydrogen embrittlement, slow-strain-rate technique, tensile test, elongation

\section{1. 緒言}

近年, 地球環境問題が深刻化し, 温暖化の抑制のため $\mathrm{CO}_{2}$ 排出量の規制が強化されている。そのため，クリーンエネ ルギーである水素の利用に関する研究が進められ，特に自 動車に関しては燃料電池自動車(FCV)が脚光を浴びている. FCVには水素を貯蔵するために,アルミニウム合金をライ ナ一材とする高压水素タンクを搭載することが提案されて いるが，一方，二三のアルミニウム合金は，湿潤大気中で 引張変形を加えると合金表面の酸化膜（バリヤ一層）が破 壊され, 式(1)の反応により発生した水素が材料内部に拡散 し延性を失い水素脆化を引き起こす場合があることが知ら れている1．

$$
2 \mathrm{Al}+3 \mathrm{H}_{2} \mathrm{O} \rightarrow \mathrm{Al}_{2} \mathrm{O}_{3}+6 \mathrm{H} \cdot \cdot \cdot(1)
$$

この反応で生じる水素は, $10^{60} \mathrm{~Pa}$ 以上の高圧のガス状水素 に相当するといわれている. 前項より, 使用中にガス圧に より引張応力が加わり，水素脆化が起らないことが保証さ れる必要がある。

そこで, 本研究では, 湿度制御した大気雾囲気中で低ひ ずみ速度引張試験(SSRT)を行い, 緻密な酸化膜を絶えず破 壊させて上記反応を起こりやすくし，アルミニウム合金の 延性に及ぼす水素の影響を調べた。

\section{2、試料および実酫方法}

\section{1 試料}

試料は，古河スカイ（株）において，溶解・鋳造，均質 化処理, 熱間圧延, 冷間圧延を経て $1 \mathrm{~mm}$ 厚とした 6061 および 7075 アルミニウム合金圧延材である。これらの化 学成分を Table.1 に示す. 6061 合金は $540^{\circ} \mathrm{C}$ で $1 \mathrm{~h}$ 保持後, 強制空冷し, 室温で $37 \mathrm{~h}$ 放置, 最終的に $175^{\circ} \mathrm{C}$ で $8 \mathrm{~h}$ 人工 時効を施した T6 処理材である(以下，6061-T6 とする)，一 方, 7075 合金は $460^{\circ} \mathrm{C}$ で $65 \mathrm{~min}$ 保持後, 水冷し, 室温で $42 \mathrm{~h}$ 放置, 最終的に $120^{\circ} \mathrm{C}$ で $24 \mathrm{~h}$ 人工時効した $\mathrm{T} 6$ 処理材 である(以下，7075-T6 とする)。これらの試料から圧延方 向と垂直方向に試料をとり，機械加工により $5 \mathrm{~mm} \times 12 \mathrm{~mm}$ の平行部を有する平板引張試験片を作製した。試料の前処 理として，\#1000 のエメリーによる研磨， $10 \% \mathrm{NaOH}$ 水 溶液によるアルカリ洗浄， $10 \% \mathrm{HNO}_{3}$ 水溶液による中和処 理, 水洗い, 乾燥を行った。

Table. 1 Composition of the specimen in mass $\%$.

\begin{tabular}{|c|c|c|c|c|c|c|c|c|}
\hline alloy & $\mathrm{Si}$ & $\mathrm{Fe}$ & $\mathrm{Cu}$ & $\mathrm{Mn}$ & $\mathrm{Mg}$ & $\mathrm{Cr}$ & $\mathrm{Zn}$ & $\mathrm{Ti}$ \\
\hline 6061 & 0.65 & 0.29 & 0.31 & 0.05 & 1.02 & 0.17 & 0.01 & 0.02 \\
\hline 7075 & 0.10 & 0.21 & 1.80 & 0.02 & 2.40 & 0.19 & 5.50 & 0.02 \\
\hline
\end{tabular}




\section{2 水素脆化感受性の評価法}

水素脆化感受性の評価は, 式(2)の $\mathrm{I}(\delta)$ を用いた。

$$
I(\delta)=1-\frac{\delta}{\delta_{0}} \cdots(2)
$$

ここで， $\delta_{0}$ : 乾燥窒素ガス(DNG)における破断伸び， $\delta ：$ 脆化環境における破断伸びである 2)3).この指数は值が大き いほど脆化感受性が大, 0 (ゼロ)で脆化感受性なし，マイナ スのとき脆化よりむしろ，延性の增加を意味する。

\section{3 実験方法}

SSRT 試験機を用いて, 初期ひずみ速度 $1.39 \times 10^{-4} \sim 3.47$ $\times 10^{-7} \mathbf{s}^{-1}$ で, 試験環境として実験室空気, 不活性基淮環境 (乾燥窒素 : DNG), 脆化㻴境 (相対湿度 $(\mathrm{RH})=\mathbf{9 0} \%$ の空

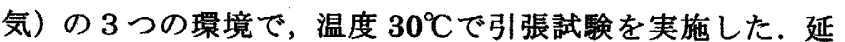
性は破断伸び $(\delta)$ で評価し, 破面を走查型電子顕微鏡 (SEM)で観察した.

\section{3. 実嗝結果および考察}

Fig.1 および Fig.2 にそれぞれ 6061-T6 および 7075-T6 について, 引張試験の結果得られた伸びと初期ひずみ速度 との関係を示す. Fig.1 から，6061-T6の延性に関しては， ひずみ速度が低くなっても伸びはほとんど変化しないこと が分かる.また, 実験室空気, $\mathrm{DNG}, 90 \% \mathrm{RH}$ の空気のど の環境においても，伸びに違いが無いことが分かる.これ に対して，Fig.2 から，7075-T6 の延性に関しては，DNG 環境ではひずみ速度が低くなっても伸びはほとんど変化し ないが，90\%RH の空気環境では低ひずみ速度ほど伸びが 低下することが分かる.この 2 つの図からひずみ速度 1.39 $\times 10^{-6} \mathbf{s}^{-1}$ において, 6061-T6 は脆化を示さず I $(\delta)$ は 0.01 となり，7075-T6 は DNG $\rightarrow \mathrm{RH} 90 \%$ の環境の変化により $\delta$ が $20.8 \rightarrow 14.4 \%$ と低下し, 高い水素脆化感受性 $\mathrm{I}(\delta)=0.31$ を示した.

Fig.3(a),(b)にはひずみ速度 $1.39 \times 10^{-6} \mathrm{~s}^{-1}, 90 \% \mathrm{RH}$ の時 の試験で得た 7075-T6 の破面を SEM で観察したものを示 した. (b)は(a)の破線で囲まれた部分を拉大したものである. (b)より，破線で囲まれた箇所で粒界割れに基づく脆性的な 破壊が起こっていることが分かり，水素脆化感受性が高か ったことに対応している。.また(a)から，脆性的な破填は試 料の表面近傍で起こっており,引張試験中に合金表面で発 生した水素が材料内部に拡散し，結晶粒間の結合力を弱め 水素脆化を引き起こしたと考えられる。

なお, 本研究は「水素安全利用等基盤技術開発一水素用 アルミ材料の基䃈研究」の一環として(社)日本アルミニウ 厶協会が新エネルギー・産業技術総合開発機構(NEDO)か ら委託を受けて行っているものであり，関係者各位に感謝 申し上げます。

\section{[参考文献]}

1)倉本 繁, 謝 明君, 菅野幹宏: 軽金属, 52(2002), $250-255$

2)大䐀修平, 堀江慎吾, 木下勝之, 佐藤 智, 安達 充, 前田环磨：軽金属，55(2005), 27-32

3)近藤秀樹, 大崎修平, 木下勝之 : 軽金属学会第 107 回秋 期大会講演会概要 (2004), 129-130



Fig.1 Strain to failure vs. strain rate for 6061-T6 stretched in some atmospheres.

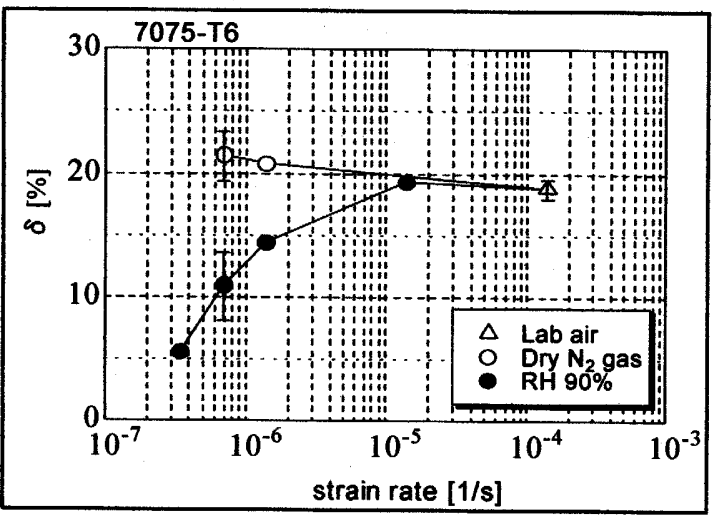

Fig.2 Strain to failure vs. strain rate for $7075 \cdot \mathrm{T} 6$ stretched in some atmospheres.
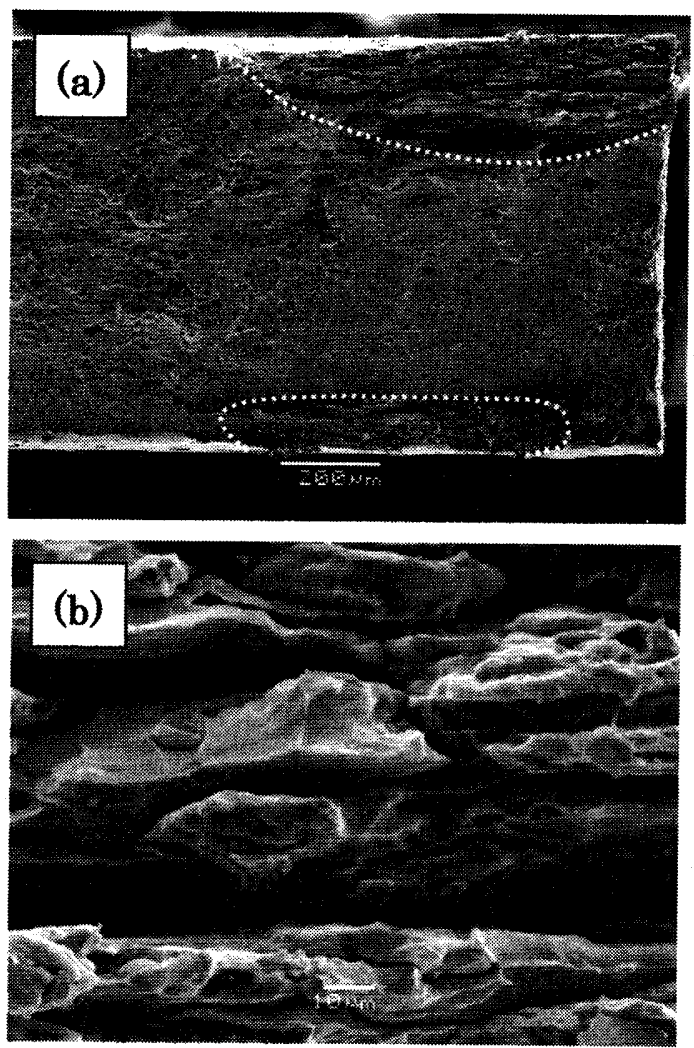

Fig.3 Scanning electron fractograph for 7075-T6 surface produced in strain rate of $1.39 \times 10^{-6} \mathrm{~s}^{-1}$ and $90 \% \mathrm{RH}$ air. (a) Low magnification, (b) High magnification 